\title{
PROFIL GURU SMK TEKNIK PEMESINAN DAN RELEVANSINYA DENGAN KURIKULUM PRODI PENDIDIKAN TEKNIK MESIN FT UNY
}

\author{
Surono \\ Fakultas Teknik Universitas Negeri Yogyakarta \\ surono.gunungkidul@gmail.com \\ Wagiran \\ Fakuta Teknik Universitas Negeri Yogyakarta \\ maswagiran@yahoo.com
}

Abstrak

Penelitian ini bertujuan untuk mengungkapkan: (1) profil ideal guru Sekolah Menengah Kejuruan (SMK) Kompetensi Keahlian Teknik Pemesinan (KKTP), (2) relevansi profil ideal guru SMK-KKTP dengan kurikulum Prodi Pendidikan Teknik Mesin Fakultas Teknik Universitas Negeri Yogyakarta (PTM FT UNY), (3) proses pembelajaran di Prodi PTM FT UNY, dan (4) profil calon guru SMKKKTP. Penelitian ini adalah penelitian kuantitatif dengan metode survei, yang dilakukan di Prodi PTM FT UNY dan sebelas SMK di provinsi DIY. Teknik pengumpulan data yang digunakan adalah dokumentasi dan angket. Teknik analisis data yang digunakan adalah analisis statistik deskriptif. Hasil penelitian adalah sebagai berikut. (1) profil ideal guru SMK-KKTP terdiri dari lima aspek kompetensi yaitu: pedagogik bidang studi keahlian, manajerial, kepribadian, dan sosial. Profil ideal guru SMKKKTP termasuk dalam kategori sangat penting. (2) Pofil ideal guru SMK-KKTP sangat relevan dengan kurikulum Prodi PTM FT UNY. Terdapat 59 kompetensi tambahan dalam kurikulum Prodi PTM FT UNY untuk menyiapkan lulusannya agar dapat bekerja di industri, menjadi instruktur, atau menjadi widyaiswara. (3) Pembelajaran di Prodi PTM FT UNY menurut persepsi dosen termasuk dalam kategori sangat memadai dan menurut persepsi mahasiswa termasuk dalam kategori memadai. (4) Profil calon guru SMK-KKTP menurut persepsi guru pembimbing PPL termasuk dalam kategori baik; menurut persepsi dosen termasuk dalam kategori baik; dan menurut persepsi mahasiswa termasuk dalam kategori baik.

Kata kunci: profil ideal guru SMK, kompetensi keahlian teknik pemesinan

\section{THE PROFILE OF VOCATIONAL HIGH SCHOOL TEACHERS OF THE MACHINING ENGINEERING AND ITS RELEVANCE TO THE CURRICULUM OF MECHANICAL ENGINEERING EDUCATION STUDY PROGRAM, FACULTY OF ENGINEERING, YOGYAKARTA STATE UNIVERSITY}

Abstract

This study aims to reveal: (1) the ideal profile of vocational high school teachers of the expertise competency of machining engineering (VET teachers of KKTP); (2) the relevance between the ideal profile of VET teachers of KKTP with the curriculum of Prodi PTM FT UNY; (3) the teaching process in Prodi PTM FT UNY; and (4) the profile of the candidates of VET teachers of KKTP. This research was quantitative research with the survey method, conducted at Prodi PTM FT UNY and eleven vocational high schools in DIY province. The data collection techniques used were documentation and questionnaires. The data analysis technique used was the descriptive statistical analysis. The result of this study is as follows. (1) The ideal profile of VET teachers of KKTP consists of five aspects competencies are: pedagogical, subject areas of expertise, managerial, personal, and social. The ideal profile of VET teachers of KKTP is in the very important category. (2) The ideal profile of VET teachers of KKTP very relevant with the curriculum of Prodi PTM FT UNY. There are 59 additional competencies in the curriculum of Prodi PTM FT UNY to prepare graduates to work in the industry, become an instructor, or become trainers. (3) The teaching process at Prodi PTM FT UNY according to the perception of lecturers is in the very adequate category and according to the perception of the students it is in the adequate category. (4) The profile of the candidates of VET teachers of KKTP according to the perception of the supervising teachers of PPL is in the good category; according to the perception of lecturers, it is in the good category; and according to the perception of students, it is in the good category.

Keywords: the ideal profile of VET teacher, the expertise competency of machining engineering 


\section{PENDAHULUAN}

Penelitian Bank Dunia tahun 2005 menyebutkan bahwa kekuatan suatu negara dalam era global ditentukan oleh: (a) inovasi dan kreativitas sebesar 45\%; (b) jaringan kerja sama sebesar 25\%; (c) teknologi sebesar 20\%, dan (d) sumber daya alam (SDA) sebesar $10 \%$ (Wagiran, 2008, p.1826). Berdasarkan hal tersebut dapat dipahami bahwa keunggulan SDA tidak berperan banyak tanpa dukungan keunggulan sumber daya manusia (SDM). Keberhasilan pembangunan SDM itu sendiri sangat ditentukan oleh keberhasilan pembangunan pendidikan yang berkualitas.

Membangun pendidikan yang berkualitas perlu dilakukan secara komprehensif mulai dari penyediaan guru, penyediaan sarana dan prasarana fisik, serta kurikulum dan sistem pembelajaran (Soeprijanto, 2010, p.1). Berdasarkan hasil studi Indra Djati Sidhi (Wagiran, 2013a, p.2) menunjukkan bahwa faktor guru memberi sumbangan yang paling besar dalam pencapaian prestasi belajar siswa yaitu $36 \%$, kemudian secara berturut-turut adalah manajemen $23 \%$, waktu belajar $22 \%$, dan sarana fisik $19 \%$. Akan tetapi, kenyataan di lapangan menunjukkan masih banyak permasalahan yang dialami terkait dengan guru dan penyiapan calon guru.

Penelitian Paryanto (2009) menyebutkan beberapa kelemahan guru dalam hal kemampuan mengajar, yaitu: (1) tidak bersikap profesional, misalnya tidak memiliki jiwa kreatif dan inovatif; (2) program pembelajaran yang dikembangkan bersifat monoton; (3) mengajar tanpa program yang jelas; (4) mengajar tidak sistematis dan jauh dari metode berpikir analitis; (5) jarang atau tidak pernah menerapkan metode pembelajaran dari hasil penelitian, karena minimnya motivasi untuk meneliti. Data pendidikan nasional Depdiknas 2007/2008 menyebutkan bahwa di SMK sekitar 23,04\% dari guru yang ada sebenarnya tidak layak menjadi guru profesional (Kompas Online 24 Oktober 2009). Sementara itu, kecenderungan kebijakan pemerintah untuk meningkatkan jumlah SMK dibanding sekolah umum akan berdampak langsung pada upaya pengadaan guru. Hal yang perlu diperhatikan dalam hal ini adalah bagaimana agar upaya peningkatan penyediaan guru ini dapat diimbangi dengan peningkatan kualitas atau mutu guru.
Upaya penyiapan calon guru yang berkualitas sering dihadapkan pada permasalahan yang berkisar pada sejauhmana mahasiswa dibekali dengan pengetahuan dan keterampilan yang mencerminkan perkembangan sistem persekolahan terkini misalnya perubahan kurikulum, perubahan bahan ajar, kemutakhiran alat praktik, dan hal lain yang berkenaan dengan tugas guru. Berbagai isu terkini juga akan berdampak pada perubahan kualifikasi guru, misalnya penerapan kurikulum 2013, Masyarakat Ekonomi ASEAN (MEA), serta penyelarasan pendidikan dengan dunia kerja yang dirumuskan dalam Kerangka Kualifikasi Nasional Indonesia (KKNI).

Penelitian Nurdjito (2010) menunjukkan bahwa pencapaian kompetensi mahasiswa Jurusan Pendidikan Teknik Mesin FT UNY (JPTM FT UNY) sebagai calon guru pemula SMK masih berada pada level cukup baik. Hal ini menuntut suatu upaya perbaikan dan peningkatan agar pencapaian kompetensi mahasiswa menjadi lebih baik. Hasil studi yang disampaikan Grollmann \& Bauer (2008, p.385) menyimpulkan bahwa belum ada profil kompetensi yang baik yang didukung oleh teori dan data empiris khususnya mengenai job description guru kejuruan. Selain itu, belum ada audit yang komprehensif berdasarkan fakta empiris mengenai kualitas dan efek dari pembelajaran yang diprakarsai oleh guru kejuruan. Berdasarkan hal tersebut, maka diperlukan perumusan profil kompetensi guru yang baik dan didasarkan pada data empiris sesuai kebutuhan di sekolah.

Berdasarkan studi yang disampaikan Grollmann \& Bauer (2008, p.386) menyimpulkan bahwa keterkaitan antara studi dan penelitian bidang akademik dengan situasi mengajar yang sebenarnya masih kurang. Dampaknya adalah kurangnya kompetensi pedagogis yang relevan untuk bekerja sebagai guru diperoleh selama studi. Dengan kata lain, relevansi antara pendidikan calon guru dengan kompetensi yang diperlukan ketika menjadi guru masih kurang.

Penjelasan dalam pedoman pengembangan kurikulum Lembaga Pendidikan Tenaga Kependidikan (LPTK) (Rustad, 2013, p.19) menyebutkan bahwa rumusan kompetensi guru dalam UU No 14 Tahun 2005 masih dirasakan bersifat fragmentaris dan tidak bisa digunakan langsung sebagai landasan penyusunan kurikulum program pendidikan 
guru. Berangkat dari temuan ini, dalam upaya standarisasi pengembangan kurikulum LPTK diperlukan reformulasi dan penegasan keutuhan kompetensi guru.

Berdasarkan uraian tentang pentingnya peran guru dalam pencapaian keberhasilan pendidikan, adanya berbagai permasalahan dalam pendidikan calon guru, serta keberadaan JPTM FT UNY sebagai lembaga yang menyiapkan calon guru SMK bidang teknik mesin, maka perlu dilakukan sebuah penelitian untuk mengungkap profil ideal guru SMK khususnya Kompetensi Keahlian Teknik Pemesinan (KKTP) dan relevansinya dengan kurikulum Program Studi Pendidikan Teknik Mesin FT UNY (Prodi PTM FT UNY).

Profil guru SMK-KKTP ini akan memberi gambaran utuh mengenai berbagai kompetensi yang harus dikuasai oleh guru SMK. Rumusan tersebut diharapkan dapat menjadi dasar pengembangan kurikulum pendidikan calon guru yang didasarkan pada need assessment yang mendalam. Relevansi antara profil ideal guru SMK dengan kurikulum LPTK harus terpenuhi dengan baik mengingat kurikulum, dosen, dan proses pembelajaran di perguruan tinggi akan menjadi acuan dan model bagi mahasiswa calon guru.

Penelitian ini bertujuan untuk mengungkapkan: (1) profil ideal guru SMK-KKTP, (2) relevansi profil ideal guru SMK-KKTP dengan kurikulum Prodi PTM FT UNY, (3) pembelajaran di Prodi PTM FT UNY, dan (4) profil calon guru SMK-KKTP. Hasil dari penelitian ini diharapkan dapat menjadi bahan kajian dan sumber informasi bagi Prodi PTM FT UNY dan Fakultas Pendidikan Teknologi Kejuruan (FPTK) lain, serta pihak pengambil kebijakan dalam pendidikan guru kejuruan untuk peningkatan mutu pendidikan dan penyiapan tenaga guru SMK yang berkualitas.

\section{METODE PENELITIAN}

Penelitian ini menggunakan metode survei yang dilaksanakan di Prodi PTM FT UNY dan sebelas SMK di provinsi DIY pada bulan Agustus sampai November 2014. Populasi dalam penelitian adalah guru SMK berjumlah 137, mahasiswa peserta PPL berjumlah 69, dan dosen dari Prodi PTM FT UNY berjumlah 9 orang (DPL PPL). Penentuan ukuran sampel mengacu pada tabel Krejcie \& Morgan (1970) dengan tingkat kepercayaan
95\%, sehingga diperoleh sampel sebagaimana ditampilkan dalam Tabel 1 yaitu guru SMK 103 orang, guru pembimbing PPL 59 orang, mahasiswa peserta PPL 59 orang, dan dosen 9 orang. Teknik sampling yang digunakan adalah proportional random sampling.

Tabel 1. Populasi dan Sampel Penelitian

\begin{tabular}{|c|c|c|c|c|c|c|}
\hline \multirow{2}{*}{ Sekolah } & \multicolumn{2}{|c|}{ Guru } & \multicolumn{2}{|c|}{$\begin{array}{c}\text { Peserta } \\
\text { PPL }\end{array}$} & \multicolumn{2}{|c|}{$\begin{array}{c}\text { Pembimbing } \\
\text { PPL }\end{array}$} \\
\hline & $\mathrm{P}$ & $S$ & $\mathrm{P}$ & $S$ & $\mathrm{P}$ & $S$ \\
\hline SMK N 2Pengasih & 22 & 17 & 8 & 7 & 8 & 8 \\
\hline SMK Muh 1 BantuL & 11 & 8 & 5 & 4 & 5 & 4 \\
\hline SMK N 1 Sedayu & 4 & 3 & 5 & 4 & 5 & 4 \\
\hline SMK N 2 Wonosari & 15 & 11 & 8 & 7 & 8 & 7 \\
\hline SMK N 2 Depok & 11 & 8 & 9 & 8 & 9 & 8 \\
\hline SMK Muh Prambanan & 19 & 14 & 5 & 4 & 5 & 4 \\
\hline SMK PIRI Sleman & 5 & 4 & 2 & 2 & 1 & 1 \\
\hline SMK Muh 3 Yogyakarta & 12 & 10 & 6 & 5 & 6 & 5 \\
\hline SMK PIRI 1 Yogyakarta & 7 & 5 & 5 & 4 & 4 & 4 \\
\hline SMK N 3 Yogyakarta & 16 & 12 & 8 & 7 & 8 & 7 \\
\hline SMK N 2 Yogyakarta & 15 & 11 & 8 & 7 & 8 & 7 \\
\hline Jumlah & 137 & 103 & 69 & 59 & 67 & 59 \\
\hline
\end{tabular}

Data kurikulum Prodi PTM FT UNY dikumpulkan dengan teknik dokumentasi. Persepsi guru, dosen, dan mahasiswa dikumpulkan dengan teknik angket, yaitu: (1) angket profil ideal guru SMK-KKTP; (2) angket pembelajaran; dan (3) angket profil calon guru SMK-KKTP. Angket dikembangkan dengan skala Likert lima alternatif pilihan sebagaimana dalam Tabel 2 berikut ini.

Tabel 2. Skor Penilaian dalam Instrumen

\begin{tabular}{llllc}
\hline No & \multicolumn{3}{c}{ Alternatif Jawaban } & Skor \\
\hline 1 & Sangat Penting & Sangat Baik & Sangat Memadai & 5 \\
2 & Penting & Baik & Memadai & 4 \\
3 & Kurang Penting & Kurang Baik Kurang Memadai & 3 \\
4 & Tidak Penting & Tidak Baik & Tidak Memadai & 2 \\
5 & Sangat Tidak & Sangat & Sangat Tidak & 1 \\
& Penting & Tidak Baik & Memadai & \\
\hline
\end{tabular}

Instrumen dalam penelitian ini telah melalui tahap validasi ahli untuk memperoleh validitas isi, yaitu Prof. Pardjono, Ph.D. dan 
Dr. B. Sentot Wijanarka. Instrumen tersebut kemudian diujicobakan untuk memperoleh validitas konstruk dengan responden berjumlah 30 orang sesuai dengan teori (Wagiran, 2013b, p.297; Widoyoko, 2013, p.146). Data kemudian dianalisis menggunakan korelasi product moment. Jika $\mathrm{r}_{\text {hitung }} \geq 0,3$ nomor butir tersebut dikatakan valid (Azwar, 2014, p.86; Wagiran, 2013b, p.300; Widoyoko, 2013, p.149). Item yang valid kemudian dianalisis reliabilitasnya dengan kaidah Cronbach Alpha. Interpretasi hasil analisis reliabilitas mengacu pendapat Sekaran (2003, p.311) yaitu jika nilainya kurang dari 0,6 adalah kurang baik; 0,7 dapat diterima; dan di atas 0,8 adalah baik.

\section{Teknik Analisis Data}

Teknik analisis data menggunakan analisis statistik deskriptif yang menyajikan: (a) distribusi frekuensi setiap variabel, (b) ukuran tendensi sentral (mean, median, mo$d u s$ ), dan (c) ukuran dispersi (standar deviasi dan varian). Skor penilaian dalam angket dikelompokkan dalam lima kategori yang secara teoritis didasarkan pada kaidah distribusi normal sebagaimana disampaikan dalam Tabel 3 (Wagiran, 2013b, p.337).

Tabel 3. Kategori Penilaian Teoritis

\begin{tabular}{cl}
\hline Interval & \multicolumn{1}{c}{ Kategori } \\
\hline$\overline{M_{\iota}}+1,8 S D_{i}<X \leq \overline{M_{\iota}}+3 S D_{i}$ & $\begin{array}{l}\text { Sangat Penting/Sangat } \\
\text { Baik/Sangat Memadai }\end{array}$ \\
$\overline{M_{\iota}}+0,6 S D_{i}<X \leq \overline{M_{\iota}}+1,8 S D_{i}$ & Penting/Baik/Memadai \\
$\overline{M_{\iota}}-0,6 S D_{i}<X \leq \overline{M_{\iota}}+0,6 S D_{i}$ & Kurang Penting/Kurang \\
& Baik/Kurang Memadai \\
$\overline{M_{\iota}}-1,8 S D_{i}<X \leq \overline{M_{\iota}}-0,6 S D_{i}$ & Tidak Penting/Tidak \\
& Baik/Tidak Memadai \\
$\overline{M_{\iota}}-3 S D_{i}<X \leq \overline{M_{\iota}}-1,8 S D_{i}$ & Sangat Tidak Penting/ \\
& Sangat Tidak Baik/ \\
& Sangat Tidak Memadai \\
\hline
\end{tabular}

Keterangan:

1. $\overline{M_{l}}=$ Rerata ideal $=1 / 2$ (skor tertinggi + skor terendah)

2. $S D_{i}=$ Simpangan baku ideal $=1 / 6$ ( skor tertinggi - skor terendah)

3. $x=$ Skor aktual

4. Skor tertinggi $=$ jumlah butir $\mathrm{x}$ skor alternatif jawaban tertinggi (5)

5. Skor terendah $=$ jumlah butir $\mathrm{x}$ skor alternatif jawaban terendah (1)
Analisis deskriptif juga digunakan untuk mengetahui pencapaian skor variabel dengan cara membandingkan skor total yang dicapai (empiris) dengan skor total tertinggi yang ditetapkan dan dinyatakan dalam persentase. Persentase tertinggi $100 \%$ dan persentase terendah $20 \%$ (5 banding 1 sesuai skor dalam skala Likert) sehingga nilai Mi sebesar $60 \%$ dan nilai SDi sebesar 13,33\%.

Tabel 4. Kriteria Interpretasi Data

\begin{tabular}{ll}
\hline Interval (\%) & \multicolumn{1}{c}{ Kategori } \\
\hline $84<\mathrm{X} \leq 100$ & $\begin{array}{l}\text { Sangat Penting/Sangat Baik/Sangat } \\
\text { Memadai }\end{array}$ \\
$68<\mathrm{X} \leq 84$ & Penting/Baik/Memadai \\
$52<\mathrm{X} \leq 68$ & $\begin{array}{l}\text { Kurang Penting/Kurang Baik/Kurang } \\
\text { Memadai }\end{array}$ \\
$36<\mathrm{X} \leq 52$ & $\begin{array}{l}\text { Tidak Penting/Tidak Baik/Tidak } \\
\text { Memadai }\end{array}$ \\
$20 \leq \mathrm{X} \leq 36$ & $\begin{array}{l}\text { Sangat Tidak Penting/Sangat Tidak } \\
\text { Baik/Sangat Tidak Memadai }\end{array}$ \\
\hline
\end{tabular}

Rumusan profil ideal guru SMK-KKTP kemudian dibandingkan dengan kurikulum Prodi PTM FT UNY untuk mengetahui relevansinya dan dinyatakan dalam persentase. Analisis selanjutnya adalah mengklasifikasikan data kompetensi dalam tiga kelompok yaitu: (1) kompetensi ada dalam rumusan profil ideal guru SMK-KKTP dan ada dalam kurikulum Prodi PTM FT UNY; (2) kompetensi ada dalam rumusan profil ideal guru SMK-KKTP tetapi tidak ada dalam kurikulum Prodi PTM FT UNY; (3) kompetensi tidak ada dalam rumusan profil ideal guru SMKKKTP tetapi ada dalam kurikulum Prodi PTM FT UNY.

\section{HASIL PENELITIAN DAN PEMBAHASAN}

\section{Urgensi Rumusan Profil Ideal Guru SMK}

Terdapat 102 butir pernyataan dalam angket. Rentang skor yang ditetapkan mulai 102 sampai dengan 510, nilai Mi sebesar 306, dan nilai SDi sebesar 68. Hasil analisis statistik deskriptif menggunakan software SPSS menunjukkan besarnya mean adalah 450,18; median 447; mode 434, standar deviasi 25,180; varian 634,054; nilai minimum 393; nilai maksimum 510; dan sum 46.369. Berdasarkan data tersebut maka besarnya range $(\mathrm{R})=510-393=117$; jumlah kelas $(\mathrm{K})=1+$ 
3,3 $\log 103=7,64$ dibulatkan menjadi 8; dan panjang interval $(\mathrm{P})=117: 8=14,625$ dibulatkan menjadi 15.

Tabel 5. Distribusi Frekuensi Data Variabel Profil Ideal Guru SMKKKTP

\begin{tabular}{ccccc}
\hline No. & Interval & Frek & Frek. Relatif & $\begin{array}{c}\text { Frek. Kumul. } \\
\text { Relatif }\end{array}$ \\
\hline 1 & $393-407$ & 4 & $3,88 \%$ & $3,88 \%$ \\
2 & $408-422$ & 8 & $7,77 \%$ & $11,65 \%$ \\
3 & $423-437$ & 25 & $24,27 \%$ & $35,92 \%$ \\
4 & $438-452$ & 26 & $25,24 \%$ & $61,17 \%$ \\
5 & $453-467$ & 13 & $12,62 \%$ & $73,79 \%$ \\
6 & $468-482$ & 15 & $14,56 \%$ & $88,35 \%$ \\
7 & $483-497$ & 7 & $6,80 \%$ & $95,15 \%$ \\
8 & $498-512$ & 5 & $4,85 \%$ & $100 \%$ \\
\hline \multicolumn{2}{c}{ Jumlah } & 103 & $100 \%$ & \\
\hline
\end{tabular}

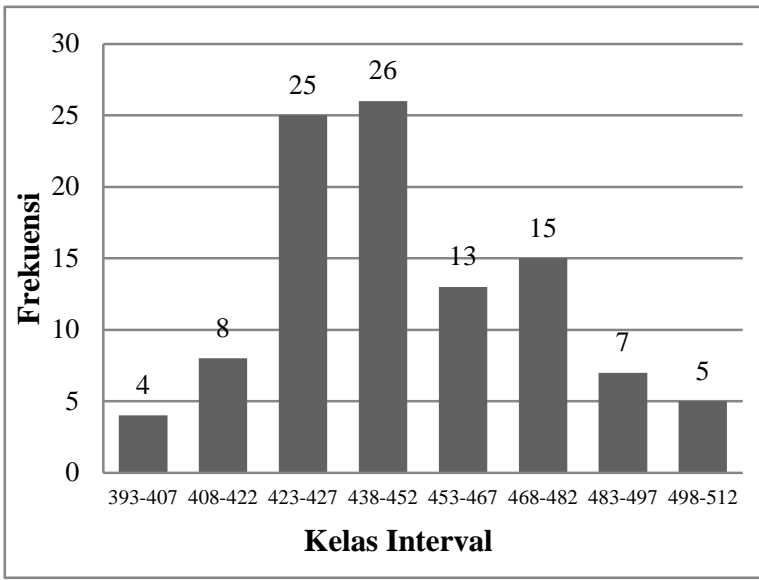

Gambar 1. Diagram Batang Distribusi Frekuensi Data Variabel Profil Ideal Guru SMK-KKTP

Rerata data hasil penelitian (empiris) adalah 450,18. Nilai tersebut lebih besar dibanding rerata kriteria sebesar 306, sehingga urgensi rumusan profil ideal guru SMKKKTP secara umum termasuk kategori penting. Kecenderungan masing-masing skornya disajikan dalam Tabel 6 dan Gambar 2.

Berdasarkan uraian Gambar 2, urgensi rumusan profil ideal guru SMK-KKTP secara umum cenderung termasuk dalam kategori penting sampai sangat penting. Hal ini selaras dengan rerata hasil penelitian yang telah dianalisis. Skor total yang diperoleh adalah 46.369 dan skor tertinggi yang ditetapkan adalah 52.530, maka pencapaian skornya ada- lah $88,27 \%$ dengan kategori sangat penting. Lima urutan teratas urgensi butir kompetensinya yaitu: (1) taat menjalankan agama yang dianut, (2) bertanggungjawab, (3) melaksanakan pembelajaran yang mendidik, (4) jujur, (5) disiplin. Sedangkan lima urutan terbawah urgensi butir kompetensinya yaitu: (1) mengelola bursa kerja, (2) merumuskan kurikulum, (3) menyusun proposal penelitian tindakan kelas, (4) melaksanakan penelitian tindakan kelas, (5) mengajar peserta didik internasional.

Tabel 6. Persentase Kecenderungan Skor Variabel Profil Ideal Guru SMKKKTP

\begin{tabular}{clcc}
\hline Interval & \multicolumn{1}{c}{ Kategori } & Frek & $\%$ \\
\hline $428,4<\mathrm{X} \leq 510$ & Sangat Penting & 82 & 80 \\
$346,8<\mathrm{X} \leq 428,4$ & Penting & 21 & 20 \\
$265,2<\mathrm{X} \leq 346,8$ & Kurang Penting & 0 & 0 \\
$183,6<\mathrm{X} \leq 265,2$ & Tidak Penting & 0 & 0 \\
$102 \leq \mathrm{X} \leq 183,6$ & Sangat Tidak Penting & 0 & 0 \\
\hline Total & $\mathbf{1 0 3}$ & $\mathbf{1 0 0 \%}$ \\
\hline
\end{tabular}

Kecenderungan skor pada variabel profil ideal guru SMK Kompetensi Keahlian Teknik Pemesinan

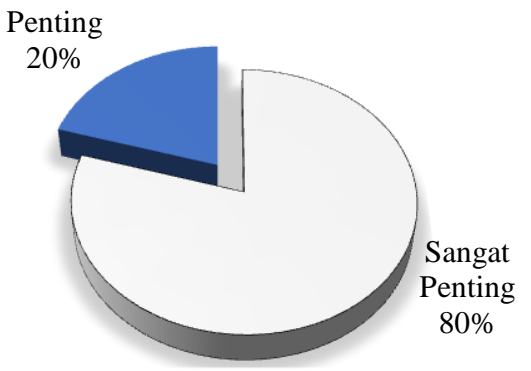

Gambar 2. Diagram Lingkaran Persentase Kecenderungan Skor Variabel Profil Ideal Guru SMKKKTP

Deskripsi hasil penelitian menunjukkan bahwa urgensi rumusan profil ideal guru SMK-KKTP secara keseluruhan dari 102 butir kompetensi termasuk kategori sangat penting. Hal ini menegaskan bahwa proses sintesis rumusan profil guru yang bersumber dari literature review antara lain peraturan atau undang-undang, SKKNI yang disampaikan BNSP dan LSP LMI, hasil penelitian yang 
relevan, dan standar yang ditetapkan oleh suatu negara/lembaga internasional sudah sesuai dengan kebutuhan di lapangan. Proses validasi dan uji coba yang telah dilakukan juga berjalan dengan efektif sehingga menghasilkan butir-butir kompetensi yang urgensinya sangat penting dan sesuai dengan kebutuhan guru SMK-KKTP. Pada aspek kompetensi pedagogik, urgensinya termasuk kategori sangat penting. Temuan ini selaras dengan berbagai rumusan (Rauner \& Dittrich, 2006, p.40; Oklahoma Panhandle State University, 2012, p.5; Dutch Foundation for Professional Teaching Competence dalam Roelofs \& Sanders, 2007, p.131; dan Deklarasi Bandung dalam Schröder, 2013, p.98) yang menyatakan bahwa guru kejuruan perlu menguasai kompetensi pedagogik.

Profil ideal guru SMK pada aspek kompetensi bidang studi keahlian sesuai hasil penelitian urgensinya termasuk kategori sangat penting. Temuan tersebut selaras dengan berbagai rumusan yang menyatakan bahwa guru kejuruan perlu menguasai kompetensi dalam bidang studi (Deklarasi Bandung dalam Schröder, 2013, p.98; Yunos, 2008, p.8; Spotti, Kamarainen, \& Dittrich dalam Wagiran, 2013a, p.62).

Rumusan profil kompetensi guru pada aspek kompetensi manajerial urgensinya termasuk dalam kategori sangat penting. Temuan tersebut sejalan dengan berbagai rumusan mengenai pentingnya kemampuan manajerial untuk dikuasai guru (Ditjen DIKTI, 2010b, p.5; Ditjen DIKTI, 2010a, p.19; Yunos, 2008, pp.8-9). Kemampuan memimpin dan mengambil keputusan menjadi hal yang paling penting sesuai perolehan skornya. Hal tersebut sesuai dengan rumusan North Carolina State Board of Education (Department of Public Instruction, 2012, p.7) yang menyatakan bahwa standar guru dalam paradigma baru abad 21 yaitu bahwa guru perlu menunjukkan kepemimpinan.

Urgensi rumusan profil guru pada aspek kompetensi kepribadian termasuk kategori sangat penting. Hal ini sesuai dengan rumusan General Directorate of Education, Vocational Training and Learning Innovation di Spanyol (2010) yang menekankan pentingnya penguasaan kompetensi kepribadian.

Urgensi rumusan profil guru pada aspek kompetensi sosial termasuk dalam kategori sangat penting. Temuan tersebut sesuai de- ngan berbagai rumusan (General Directorate of Education, Vocational Training and Learning Innovation di Spanyol, 2010; Scientific Report about Standards, tt, p.21) yang menjelaskan bahwa kompetensi sosial merupakan salah satu kompetensi yang harus dikuasai oleh guru.

\section{Profil Ideal Guru SMK-KKTP}

Berdasarkan analisis diketahui bahwa dari 102 butir kompetensi secara keseluruhan termasuk kategori penting atau sangat penting dengan persentase pencapaian skor di atas $68 \%$. Oleh karena itu, profil ideal guru SMKKKTP terdiri atas 102 butir (Tabel 7-11).

Tabel 7. Kompetensi Pedagogik

\begin{tabular}{l} 
No Kompetensi Pedagogik \\
\hline 1. Memahami karakteristik peserta didik \\
2. Memperlakukan peserta didik sesuai karakteristiknya \\
3. Menguasai model pembelajaran \\
4. Menyusun rancangan pembelajaran \\
5. Melaksanakan pembelajaran \\
6. Mengelola kelas \\
7. Mengelola pembelajaran \\
8. Mengajar peserta didik internasional \\
9. Menyelenggarakan pembelajaran berbasis kompetensi \\
10. Menyelenggarakan pembelajaran berbasis proyek \\
(project based learning) \\
11. Menyelenggarakan pembelajaran berbasis kerja (work \\
based learning) \\
12. Menyelenggarakan pembelajaran kontekstual \\
13. Memahami proses penyusunan kurikulum \\
14. Merumuskan kurikulum \\
15. Mengaplikasikan kurikulum \\
16. Menyusun silabus \\
17. Menyusun RPP \\
18. Memanfaatkan teknologi informasi dan komunikasi \\
19. Memanfaatkan multimedia yang relevan dengan mata \\
pelajaran \\
20. Mempresentasikan materi dengan efektif menggunakan \\
media pembelajaran \\
21. Merencanakan penilaian \\
22. Mengembangkan instrumen penilaian \\
23. Melaksanakan penilaian yang beranekaragam \\
24. Memberi umpan balik terhadap tugas \\
25. Melaporkan hasil penilaian \\
26. Mengidentikanan alternatif pemecahan masalah pembelajaran \\
30. Menyusun proposal penelitian tindakan kelas \\
31. Melaksanakan penelitian tindakan kelas \\
27. Memanfaatkan hasil refleksi untuk perbaikan \\
26an
\end{tabular}


Tabel 8. Kompetensi Bidang Studi Keahlian

\begin{tabular}{|c|c|}
\hline No & Kompetensi Bidang Studi Keahlian \\
\hline & Menjelaskan pokok bahasan secara tepat \\
\hline 33. & Mengembangkan materi pelajaran secara kreatif \\
\hline 34. & $\begin{array}{l}\text { Memberi contoh yang relevan dengan materi yang } \\
\text { diajarkan }\end{array}$ \\
\hline 35. & $\begin{array}{l}\text { Menjelaskan keterkaitan bidang/topik yang diajarkan } \\
\text { dengan bidang/topik lain }\end{array}$ \\
\hline 36. & $\begin{array}{l}\text { Menjelaskan keterkaitan bidang/topik yang diajarkan } \\
\text { dengan konteks kehidupan }\end{array}$ \\
\hline 37. & Menguasai isu-isu mutakhir dalam bidang yang diajarkan \\
\hline 38. & Mengikuti perkembangan teknologi pembelajaran \\
\hline 39. & Memahami dasar kekuatan bahan dan komponen mesin \\
\hline 40. & Memahami prinsip dasar kelistrikan dan konversi energi \\
\hline 41. & Memahami proses dasar perlakuan logam \\
\hline & Memahami proses dasar teknik mesin \\
\hline & Menerapkan keselamatan dan kesehatan kerja (K3) \\
\hline & Melaksanakan penanganan material secara manual \\
\hline & $\begin{array}{l}\text { Menggunakan peralatan pembandingan dan/atau alat } \\
\text { ukur dasar }\end{array}$ \\
\hline & Mengukur dengan alat ukur mekanik presisi \\
\hline & Menggunakan perkakas tangan \\
\hline & Menggunakan perkakas bertenaga/operasi digenggam \\
\hline & Menginterpretasikan sketsa \\
\hline & Membaca gambar teknik \\
\hline & Menggunakan mesin untuk operasi dasar \\
\hline 52. & Melakukan pekerjaan dengan mesin bubut \\
\hline 53. & Melakukan pekerjaan dengan mesin frais \\
\hline 54. & Melakukan pekerjaan dengan mesin gerinda \\
\hline & Menggunakan mesin bubut (kompleks) \\
\hline & Memfrais (kompleks) \\
\hline 57. & Menggerinda pahat dan alat potong \\
\hline & Mengeset mesin dan program mesin NC/CNC (dasar) \\
\hline 59. & Memprogram mesin NC/CNC (dasar) \\
\hline 60. & Mengoperasikan mesin NC/CNC (Dasar) \\
\hline & $\begin{array}{l}\text { Menggambar dengan sistem CAD (Computer-Aided } \\
\text { Drafting) }\end{array}$ \\
\hline
\end{tabular}

Tabel 9. Kompetensi Manajerial

\begin{tabular}{|c|c|}
\hline No & Kompetensi Manajerial \\
\hline & Memiliki jiwa kepemimpinan \\
\hline 63. & Memimpin/mengelola organisasi \\
\hline 64. & $\begin{array}{l}\text { Mengambil keputusan strategis berdasarkan analisis } \\
\text { informasi dan data }\end{array}$ \\
\hline & Mengelola lembaga sekolah \\
\hline & Mengelola laboratorium/bengkel \\
\hline & Mengelola unit produksi \\
\hline & Mengelola bursa kerja \\
\hline
\end{tabular}

Tabel 10. Kompetensi Kepribadian

\begin{tabular}{ll}
\hline No & \multicolumn{1}{c}{ Kompetensi Kepribadian } \\
\hline 69. & Taat menjalankan agama yang dianut \\
70. Bertoleransi \\
71. Arif \\
72. Berwibawa \\
73. Bangga menjadi guru \\
74. Mencintai pekerjaan \\
75. Percaya diri \\
76. Jujur \\
77. Inovatif \\
78. Disiplin \\
79. Bertanggungjawab \\
80. Mandiri \\
81. Berpikir kritis \\
82. Memiliki etos kerja \\
83. Memecahkan masalah secara kreatif \\
84. Mengendalikan diri dalam berbagai situasi \\
85. Stabil \\
86. Dewasa \\
87. Memahami kode etik profesi guru \\
88. Berperilaku sesuai dengan kode etik profesi guru \\
89. Menjadi contoh dalam berperilaku \\
90. Bersikap adil dalam memperlakukan siswa \\
\hline
\end{tabular}

Tabel 11. Kompetensi Sosial

\begin{tabular}{l}
\hline No \\
\hline 91. Menyampaikan pendapat dengan baik \\
92. Terbuka terhadap saran/kritik/pendapat orang lain \\
93. Berkomunikasi secara baik dalam bentuk lisan \\
maupun tulisan \\
94. Bersikap objektif dalam melaksanakan pembelajaran \\
95. Tidak bersikap diskriminatif dalam melaksanakan \\
pembelajaran \\
96. Bekerjasama dalam tim \\
97. Berkolaborasi dengan rekan kerja \\
98. Beradaptasi dengan lingkungan tempat bekerja \\
untuk meningkatkan efektivitas sebagai pendidik \\
99. Fleksibel dalam menyesuaikan diri \\
100. Membimbing diskusi siswa \\
101. Melaksanakan bimbingan kejuruan \\
102. Melaksanakan bimbingan karier
\end{tabular}

Kompetensi pedagogik, kompetensi kepribadian, dan kompetensi sosial dalam rumusan profil ideal hasil penelitian ini secara garis besar memiliki kesamaan dengan rumusan kompetensi sesuai Undang-Undang Nomor 14 Tahun 2005 tentang Guru dan Dosen yang 
dijabarkan lebih lanjut dalam Permendiknas Nomor 16 Tahun 2007 tentang Standar Kualifikasi Akademik dan Kompetensi Guru, dan Peraturan Pemerintah Nomor 74 Tahun 2008 tentang Guru. Dua kompetensi lain yaitu kompetensi bidang studi keahlian dan kompetensi manajerial merupakan temuan dalam penelitian yang membedakan dengan rumusan kompetensi berdasarkan konteks kebijakan yang berlaku di Indonesia sebelumnya.

Penyebutan kompetensi profesional berdasarkan konteks kebijakan yang berlaku di Indonesia jika ditinjau lebih jauh adalah kurang tepat. Seharusnya, istilah kompetensi profesional sudah mewadahi atau mencakup keseluruhan kompetensi. Akan tetapi, sesuai penjelasan dalam kebijakan tersebut hanya menyatakan bahwa kompetensi profesional merupakan kemampuan penguasaan materi pelajaran secara luas dan mendalam. Oleh karena itu, akan lebih tepat jika kompetensi profesional disebut dengan kompetensi bidang studi keahlian. Hal ini selaras dengan pendapat yang disampaikan Suyanto \& Djihad, (2013, p.52) dan sesuai dengan Pedoman Pengembangan Kurikulum LPTK yang disampaikan Dirjen DIKTI (Rustad, 2013, pp.1922).

Rumusan kompetensi bidang studi keahlian memuat uraian kompetensi spesifik sesuai bidang keahlian seorang guru, dalam hal ini adalah guru SMK-KKTP. Rumusan kompetensi spesifik ini akan sejalan dengan pengembangan kurikulum LPTK dan kaitannya dengan KKNI. Kompetensi spesifik yang harus dikuasai lulusan ini dapat dijadikan sebagai bagian dalam rumusan profil lulusan LPTK. Profil lulusan tersebut didasarkan dari deskripsi generik dalam KKNI yang dikembangkan menjadi deskripsi spesifik sesuai dengan bidang ilmu dan atau program studi, dan digunakan untuk menetapkan capaian pembelajaran program studi (Program Learning Outcomes) sesuai penjelasan oleh Rustad (2013, p.13).

Kompetensi manajerial yang dimasukkan dalam rumusan profil ideal guru SMKKKTP merupakan temuan lainnya dalam penelitian ini. Kompetensi manajerial ini sebelumnya tidak ada dalam rumusan kompetensi berdasarkan konteks kebijakan yang berlaku di Indonesia. Dimasukkannya kompetensi manajerial dalam rumusan profil ideal guru SMK-KKTP ini dikarenakan dalam ke- nyataannya di lapangan, guru selain harus mengajar juga memiliki tugas tambahan misalnya sebagai pengawas, kepala, wakil kepala, kepala laboratorium, kepala bengkel, atau kepala unit produksi satuan pendidikan sesuai dengan amanat Permendiknas Nomor 39 Tahun 2009 tentang Pemenuhan Beban Kerja Guru dan Pengawas Satuan Pendidikan. Oleh karena itu, diharapkan guru yang memiliki penguasaan kompetensi manajerial ini dapat memenuhi tugas tersebut dengan baik.

Perlunya penguasaan kompetensi manajerial oleh guru ini juga sesuai dengan KKNI. Diketahui bahwa deskriptor pada KKNI terbagi atas dua bagian yaitu deskripsi umum dan deskripsi spesifik. Salah satu unsur utama dalam deskripsi spesifik adalah kemampuan manajerial (Ditjen DIKTI, 2010a, p.19; Dirjen DIKTI, 2010b, p.5). Temuan tersebut semakin menguatkan pandangan bahwa selain harus menguasai empat kompetensi yaitu kompetensi pedagogik, kompetensi bidang studi keahlian, kompetensi kepribadian, dan kompetensi sosial sesuai penjelasan sebelumnya, maka guru juga harus menguasai kompetensi manajerial.

\section{Capaian Tingkat Kesesuaian Profil Ideal Guru SMK-KKTP dengan Kurikulum Prodi PTM FT UNY Option Pemesinan}

Capaian tingkat kesesuaian diperoleh dengan cara membandingkan rumusan profil ideal guru SMK-KKTP dengan kurikulum Prodi PTM FT UNY pada option pemesinan dengan melibatkan Kaprodi PTM FT UNY yaitu Dr. B. Sentot Wijanarka. Rumusan profil ideal guru SMK-KKTP ditabulasi dan digunakan sebagai check list perbandingan kurikulum. Berdasarkan hasil analisis, relevansi antara profil ideal guru SMK-KKTP dengan kurikulum Prodi PTM FT UNY mencapai $100 \%$. Artinya, 102 kompetensi yang ada dalam rumusan profil ideal guru SMKKKTP telah ada/diajarkan dalam kurikulum Prodi PTM FT UNY khususnya option pemesinan.

Pencapaian tersebut dikarenakan seluruh mata kuliah dan segala proses pembelajaran yang dilaksanakan di Prodi PTM FT UNY telah sesuai/relevan dengan kebutuhan seorang guru teknik pemesinan di lapangan. Kompetensi yang harus dikuasai guru di SMK telah ada dan dan difasilitasi di Prodi PTM FT UNY, yang terwujud dalam mata kuliah, kom- 
petensi yang dikembangkan, maupun segala fasilitas yang dapat diakses oleh mahasiswa di kampus.

\section{Klasifikasi Kompetensi yang Ada dalam Rumusan Profil Ideal Guru SMK-KKTP dengan Kompetensi dalam Kurikulum Prodi PTM FT UNY}

Analisis lanjutan dilakukan untuk mengetahui klasifikasi antara kompetensi yang ada dalam rumusan profil ideal guru SMK-KKTP dengan kompetensi dalam kurikulum Prodi PTM FT UNY. Hasil analisis disampaikan dalam Tabel 12 berikut ini.

Tabel 12. Klasifikasi Kompetensi

\begin{tabular}{|c|c|c|}
\hline $\begin{array}{l}\text { Kurikulum } \\
\text { Prodi PTM FT UNY }\end{array}$ & $\begin{array}{l}\text { Kompetensi ada } \\
\text { dalam Rumusan } \\
\text { Profil Ideal } \\
\text { Guru SMK- } \\
\text { KKTP }\end{array}$ & $\begin{array}{l}\text { Kompetensi tidak } \\
\text { ada dalam } \\
\text { Rumusan Profil } \\
\text { Ideal Guru SMK- } \\
\text { KKTP }\end{array}$ \\
\hline $\begin{array}{l}\text { Kompetensi ada dalam } \\
\text { kurikulum Prodi PTM } \\
\text { FT UNY }\end{array}$ & 102 & 59 \\
\hline $\begin{array}{l}\text { Kompetensi tidak ada } \\
\text { dalam kurikulum Prodi } \\
\text { PTM FT UNY }\end{array}$ & 0 & \\
\hline
\end{tabular}

59 kompetensi tambahan tersebut tersebar dalam 16 mata kuliah (Tabel 13)

Tabel 13. Kompetensi Tambahan dalam Kurikulum Prodi PTM FT UNY

\begin{tabular}{|c|c|c|}
\hline No & Kompetensi Tambahan & Mata Kuliah \\
\hline & $\begin{array}{l}\text { Menjelaskan klasifikasi polimer, karak- } \\
\text { teristiknya dan aplikasinya di industri } \\
\text { Menjelaskan bahan keramik-komposit, } \\
\text { karakteristiknya dan aplikasinya di in- } \\
\text { dustri }\end{array}$ & $\begin{array}{l}\text { Bahan } \\
\text { Teknik Dasar }\end{array}$ \\
\hline & $\begin{array}{l}\text { Memahami prinsip-prinsip lubrikasi dan } \\
\text { keausan (tribology) yang terjadi pada } \\
\text { proses pemesinan logam }\end{array}$ & \multirow{3}{*}{$\begin{array}{l}\text { Teori } \\
\text { Pemesinan } \\
\text { Dasar }\end{array}$} \\
\hline & $\begin{array}{l}\text { Menganalisa kemungkinan keausan pa- } \\
\text { hat yang dominan terjadi pada proses } \\
\text { pemesinan logam }\end{array}$ & \\
\hline & $\begin{array}{l}\text { Memperkirakan umur pakai ekonomis } \\
\text { suatu alat potong yang digunakan untuk } \\
\text { proses pemesinan }\end{array}$ & \\
\hline & $\begin{array}{l}\text { Melakukan pembentukan bahan dengan } \\
\text { cara menempa }\end{array}$ & $\begin{array}{l}\text { Praktik } \\
\text { Pembentukan } \\
\text { Bahan }\end{array}$ \\
\hline & $\begin{array}{l}\text { Memahami pelumas dan pelumasan } \\
\text { pada proses manufacturing logam }\end{array}$ & $\begin{array}{l}\text { Bahan } \\
\text { Teknik }\end{array}$ \\
\hline & $\begin{array}{l}\text { Memahami proses pembentukan bahan } \\
\text { plastik }\end{array}$ & Lanjut \\
\hline
\end{tabular}

\begin{tabular}{|c|c|}
\hline Kompetensi Tambahan & Mata Kuliah \\
\hline 9. Memahami proses metalurgi serbuk & \\
\hline $\begin{array}{l}\text { 10. Mampu melakukan perlakuan } \\
\text { permukaan dengan caburizing }\end{array}$ & \\
\hline $\begin{array}{l}\text { 11. Mampu melakukan proses ekstrusi ba- } \\
\text { han plastik }\end{array}$ & \\
\hline $\begin{array}{l}\text { 12. Menggunakan alat perkakas Mesin Bor } \\
\text { Tekan }\end{array}$ & \multirow{2}{*}{$\begin{array}{l}\text { Proses } \\
\text { Pemesinan } \\
\text { Dasar }\end{array}$} \\
\hline $\begin{array}{l}\text { 13. Menggunakan alat perkakas Mesin } \\
\text { Sekrap }\end{array}$ & \\
\hline
\end{tabular}

14. Penyetelan dan penggunaan peralatan las Oksi-asitelen

15. Pengelasan Oksi-Asetilene

16. Pembrasingan pada plat dan pipa

Praktik Las

Oksi Asetilin

(OAW)

17. Pemotongan menggunakan las Oksiasitelen

\begin{tabular}{ll}
\hline $\begin{array}{l}\text { 18. Menggunakan alat perkakas mesin slot } \\
\text { dan kelengkapannya }\end{array}$ & $\begin{array}{l}\text { Proses } \\
\text { Pemesinan } \\
\text { Lanjut }\end{array}$ \\
\hline
\end{tabular}

19. Pengelasan plat baja karbon posisi down hand

20. Pengelasan plat baja karbon posisi horisontal

21. Pengelasan plat baja karbon posisi vertikal

22. Pengelasan plat baja karbon posisi over head
Praktik Las

Busur

(SMAW)
23. Maintenance \& repair

24. Membuat SOP pengelasan

25. Melakukan uji visual sambungan las SMAW

26. Mengetahui konsep dasar tentang konsep kimia

27. Mengetahui konsep dasar tentang analisis reaksi kimia serta penerapan ilmu kimia pada kimia praktis

Kimia

Teknik

28. Mengetahui dan memahami penerapan ilmu kimia pada berbagai industri

29. Memahami perilaku fluida baik dalam kondisi diam maupun bergerak

30. Mampu memberdayakan potensi energi fluida dalam desain dan analisis teknik Fluida

Mekanika

31. Melakukan antisipasi atas efek positif maupun efek negatif perilaku fluida baik cair maupun gas

32. Mengenal manajemen perawatan

33. Memahami aktivitas perawatan preventif

34. Memahami teknik diagnosa kerusakan mesin

Perawatan

5. Memahami teknik bongkar pasang komponen mesin

dan

Perbaikan

Mesin

36. Memahami teknik perbaikan komponen

37. Memahami jenis pelumas dan teknik pelumasan 


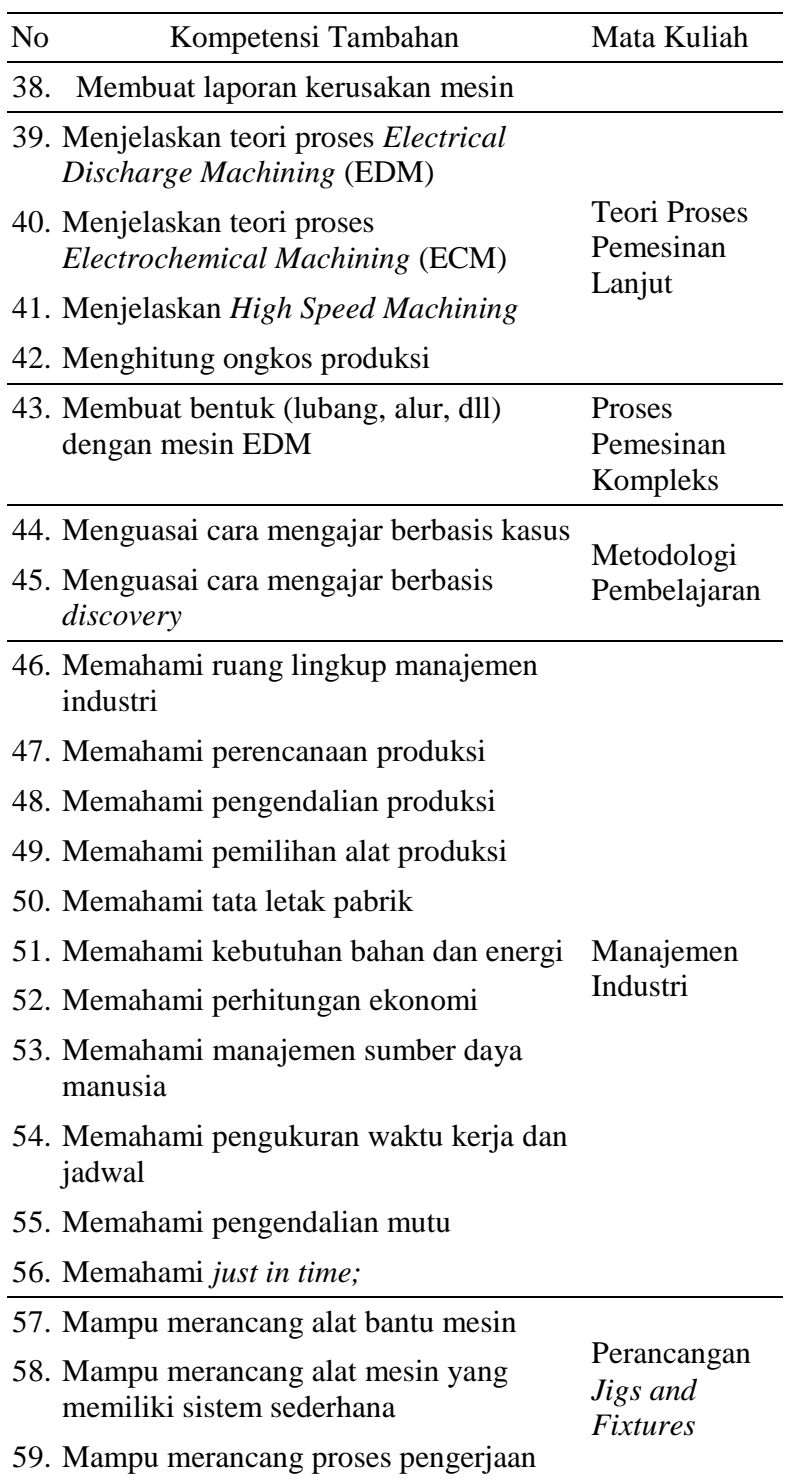

Bekal kompetensi tambahan yang diajarkan di Prodi PTM FT UNY tersebut antara lain karena Prodi PTM FT UNY selain menyiapkan lulusannya sebagai calon guru SMK juga menyiapkan lulusannya untuk dapat berkiprah di industri misalnya sebagai foreman atau supervisor, menjadi instruktur, atau menjadi widyaiswara.

\section{Pembelajaran di Prodi PTM FT UNY Menurut Persepsi Dosen}

Butir pernyataan dalam instrumen berjumlah 84 . Rentang skor yang ditetapkan adalah 84 sampai dengan 420, nilai Mi sebesar 252, dan nilai SDi sebesar 56. Hasil analisis menunjukkan bahwa besarnya mean adalah 353,89 ; median 370; mode 281; standar deviasi 43,225 ; varian 1868,361 ; nilai minimum 281; nilai maksimum 402; dan sum 3.185.
Berdasarkan data tersebut dapat ditentukan besarnya range $(R)=402-281=121$; jumlah kelas $(\mathrm{K})=1+3,3 \log 9=4,15$ jumlah kelas yang dipakai adalah 5; dan panjang interval $(\mathrm{P})=121: 5=24,2$ pada penyusunan tabel digunakan panjang interval 25. Penyebaran skornya disajikan pada Tabel 14 dan Gambar 3.

Tabel 14. Distribusi Frekuensi Data Variabel Pembelajaran Menurut Persepsi Dosen

\begin{tabular}{ccccc}
\hline No & Interval & Frek & Frek.Relatif & $\begin{array}{c}\text { Frek.Kumulatif } \\
\text { Relatif }\end{array}$ \\
\hline 1 & $281-305$ & 1 & $11,11 \%$ & $11,11 \%$ \\
2 & $306-330$ & 2 & $22,22 \%$ & $33,33 \%$ \\
3 & $331-355$ & 1 & $11,11 \%$ & $44,44 \%$ \\
4 & $356-380$ & 1 & $11,11 \%$ & $55,56 \%$ \\
5 & $381-405$ & 4 & $44,44 \%$ & $100,00 \%$ \\
\hline Jumlah & 9 & $100 \%$ & \\
\hline
\end{tabular}

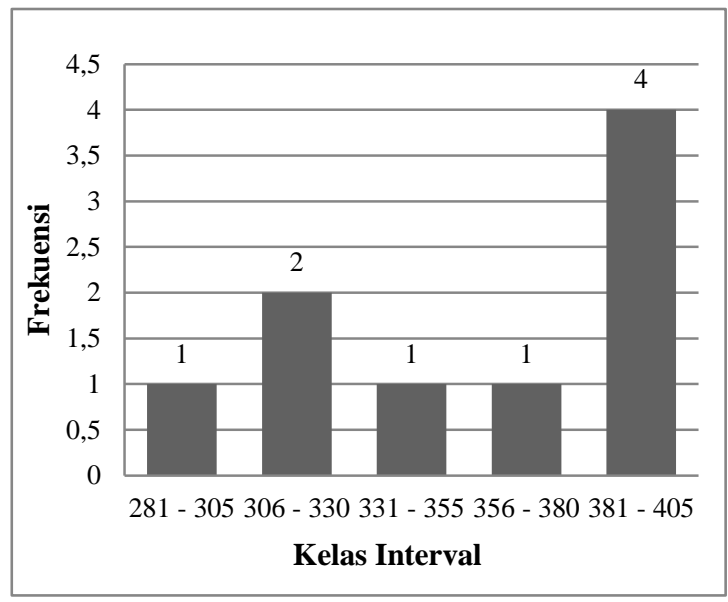

Gambar 3. Diagram Batang Distribusi Frekuensi Data Variabel Pembelajaran Menurut Persepsi Dosen

Rerata data hasil penelitian (empiris) sebesar 353,89. Nilai tersebut lebih besar dibanding rerata kriteria sebesar 252 , sehingga pembelajaran menurut persepsi dosen termasuk kategori memadai. Kecenderungan dari masing-masing skor disajikan dalam Tabel 15 dan Gambar 4 berikut ini.

Berdasarkan Gambar 4, diketahui bahwa pembelajaran menurut persepsi dosen cenderung termasuk kategori kurang memadai sampai sangat memadai. Skor total yang diperoleh adalah 3.185 dan skor tertinggi yang ditetapkan adalah 3.780, maka pencapaian 
skornya adalah 84,26\% dengan kategori sangat memadai. Artinya, pembelajaran yang dilaksanakan telah mampu dan sangat memadai untuk membekali mahasiswa dengan kompetensi yang dibutuhkan sebagai calon guru SMK-KKTP. Namun demikian, masih ada upaya yang harus dilakukan untuk meningkatkan kualitas pembelajaran. Responden berpendapat bahwa untuk lebih meningkatkan kualitas pembelajaran, diperlukan adanya benchmarking pembelajaran di Prodi PTM FT UNY dengan profil guru SMK ideal. Selain itu, observasi dan koordinasi dengan lembaga pendidikan kejuruan juga perlu ditingkatkan.

Tabel 15. Persentase Kecenderungan Skor pada Variabel Pembelajaran Menurut Persepsi Dosen

\begin{tabular}{clcc}
\hline Interval & \multicolumn{1}{c}{ Kategori } & Frek & $\%$ \\
\hline $352,8<\mathrm{X} \leq 420$ & Sangat Memadai & 5 & 56 \\
$285,6<\mathrm{X} \leq 352,8$ & Memadai & 3 & 33 \\
$218,4<\mathrm{X} \leq 285,6$ & Kurang Memadai & 1 & 11 \\
$151,2<\mathrm{X} \leq 218,4$ & Tidak Memadai & 0 & 0 \\
$84 \leq \mathrm{X} \leq 151,2$ & Sangat Tidak Memadai & 0 & 0 \\
\hline & Total & 9 & $100 \%$ \\
\hline
\end{tabular}

Kecenderungan Skor Variabel

Pembelajaran Menurut Persepsi Dosen Kurang

Memadai

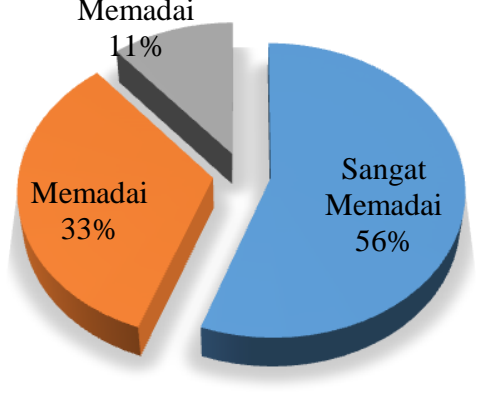

Gambar 4. Diagram Lingkaran Persentase Kecenderungan Skor Variabel Pembelajaran di Prodi PTM FT UNY Menurut Persepsi Dosen

\section{Pembelajaran di Prodi PTM FT UNY Menurut Persepsi Mahasiswa}

Butir pernyataan dalam instrumen berjumlah 84 . Rentang skor yang ditetapkan mulai 84 sampai dengan 420, nilai Mi sebesar
252, dan nilai SDi 56. Hasil analisis statistik deskriptif menunjukkan besarnya mean 327,14; median 326; mode 326; standar deviasi 28,159 ; varian 792,947 ; nilai minimum 271; nilai maksimum 396; dan jumlah skor total 19.301. Berdasarkan data tersebut, maka besarnya range $(\mathrm{R})=396-271=125$; jumlah kelas $(\mathrm{K})=1+3,3 \log 59=6,84$ dibulatkan menjadi 7; dan panjang interval $(\mathrm{P})=125: 7$ $=17,86$ dan dibulatkan menjadi 18 .

Tabel 16. Distribusi Frekuensi Data Variabel Pembelajaran Menurut Persepsi Mahasiswa

\begin{tabular}{ccccc}
\hline No & Interval & Frek & Frek.Relatif & $\begin{array}{c}\text { Frek.Kumulatif } \\
\text { Relatif }\end{array}$ \\
\hline 1 & $271-288$ & 5 & $8 \%$ & $8 \%$ \\
2 & $289-306$ & 8 & $14 \%$ & $22 \%$ \\
3 & $307-324$ & 13 & $22 \%$ & $44 \%$ \\
4 & $325-342$ & 17 & $29 \%$ & $73 \%$ \\
5 & $343-360$ & 9 & $15 \%$ & $88 \%$ \\
6 & $361-378$ & 3 & $5 \%$ & $93 \%$ \\
7 & $379-396$ & 4 & $7 \%$ & $100 \%$ \\
\hline \multicolumn{5}{l}{ Jumlah } \\
\hline
\end{tabular}

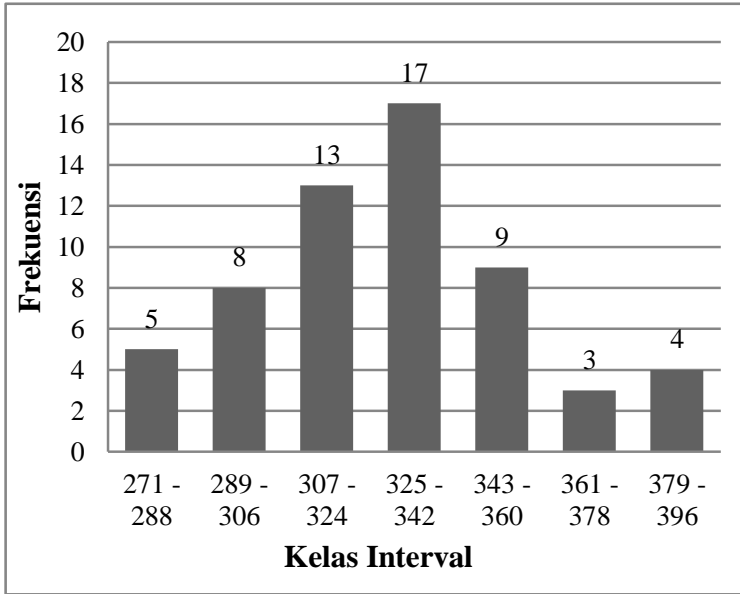

Gambar 5. Diagram Batang Distribusi Frekuensi Data Variabel Pembelajaran Menurut Persepsi Mahasiswa

Rerata data hasil penelitian (empiris) sebesar 327,14. Nilai tersebut lebih besar dibanding rerata kriteria sebesar 252, sehingga pembelajaran menurut persepsi mahasiswa secara keseluruhan termasuk kategori memadai. Kecenderungan masing-masing skor disajikan dalam Tabel 17 dan Gambar 6. 
Tabel 17. Persentase Kecenderungan Skor pada Variabel Pembelajaran Menurut Persepsi Mahasiswa

\begin{tabular}{llcc}
\hline \multicolumn{1}{c}{ Interval } & \multicolumn{1}{c}{ Kategori } & Frek & $\%$ \\
\hline $352,8<\mathrm{X} \leq 420$ & Sangat Memadai & 9 & $15,25 \%$ \\
$285,6<\mathrm{X} \leq 352,8$ & Memadai & 45 & $76,27 \%$ \\
$218,4<\mathrm{X} \leq 285,6$ & Kurang Memadai & 5 & $8,47 \%$ \\
$151,2<\mathrm{X} \leq 218,4$ & Tidak Memadai & 0 & $0,00 \%$ \\
$84 \leq \mathrm{X} \leq 151,2$ & Sangat Tidak Memadai & 0 & $0,00 \%$ \\
\hline & Total & 59 & $100 \%$ \\
\hline
\end{tabular}

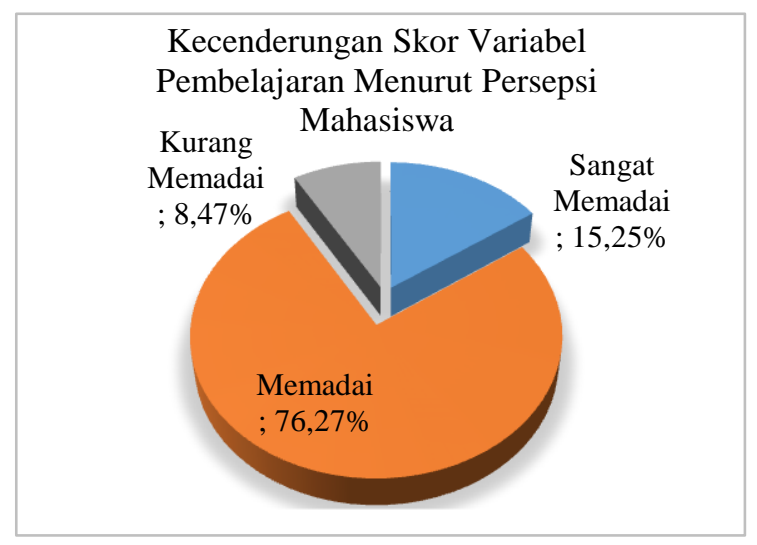

Gambar 6. Diagram Lingkaran Persentase Kecenderungan Skor Variabel Pembelajaran di Prodi PTM FT UNY Menurut Persepsi Mahasiswa

Berdasarkan Gambar 6, diketahui bahwa pembelajaran menurut persepsi mahasiswa termasuk dalam kategori kurang memadai sampai sangat memadai. Skor total yang diperoleh adalah 19.301 dan skor tertinggi yang ditetapkan adalah 24.780 , maka pencapaian skornya adalah $77,89 \%$ dengan kategori memadai. Menurut mahasiswa, agar pembelajaran menjadi lebih efektif, diperlukan pembekalan yang baik mengenai pengetahuan dan pemahaman karakteristik calon guru yang dibutuhkan di lapangan. Mahasiswa berpendapat perlu diadakan kunjungan ke sekolah untuk mengetahui kompetensi guru yang dibutuhkan di sekolah sehingga dapat melihat, meniru, dan memodifikasi sesuai kebutuhan dalam pembelajaran.

\section{Profil Calon Guru SMK-KKTP Menurut Persepsi Guru Pembimbing PPL}

Jumlah pernyataan dalam instrumen adalah 65. Rentang skor yang ditetapkan adalah mulai 65 sampai dengan 325, nilai Mi se- besar 195, dan nilai SDi 43,33. Hasil analisis statistik deskriptif menggunakan software SPSS menunjukkan nilai mean sebesar 257,14; median 260; dan mode 251. Data tersebut memiliki standar deviasi 20,388 dan varian 415,671 . Nilai minimum yang diperoleh adalah 180 , nilai maksimumnya 308 , dan jumlah skor total adalah 15.171. Berdasarkan data tersebut dapat ditentukan besarnya range $(\mathrm{R})=308-180=128$; jumlah kelas $(\mathrm{K})=1+$ 3,3 $\log 59=6,84$ dibulatkan menjadi 7; dan panjang interval $(\mathrm{P})=128: 7=18,29$ pada penyusunan tabel digunakan panjang interval 19. Penyebaran skor datanya disajikan dalam Tabel 18 dan Gambar 7.

Tabel 18. Distribusi Frekuensi Data Variabel Profil Calon Guru SMKKKTP Menurut Persepsi Guru Pembimbing PPL

\begin{tabular}{ccccc}
\hline No & Interval & Frek & Frek.Relatif & Frek.Kumulatif Relatif \\
\hline 1 & $180-198$ & 2 & $3 \%$ & $3 \%$ \\
2 & $199-217$ & 0 & $0 \%$ & $3 \%$ \\
3 & $218-236$ & 4 & $7 \%$ & $10 \%$ \\
4 & $237-255$ & 18 & $31 \%$ & $41 \%$ \\
5 & $256-274$ & 29 & $49 \%$ & $90 \%$ \\
6 & $275-293$ & 5 & $8 \%$ & $98 \%$ \\
7 & $294-312$ & 1 & $2 \%$ & $100 \%$ \\
\hline Jumlah & 59 & $100 \%$ & \\
\hline
\end{tabular}

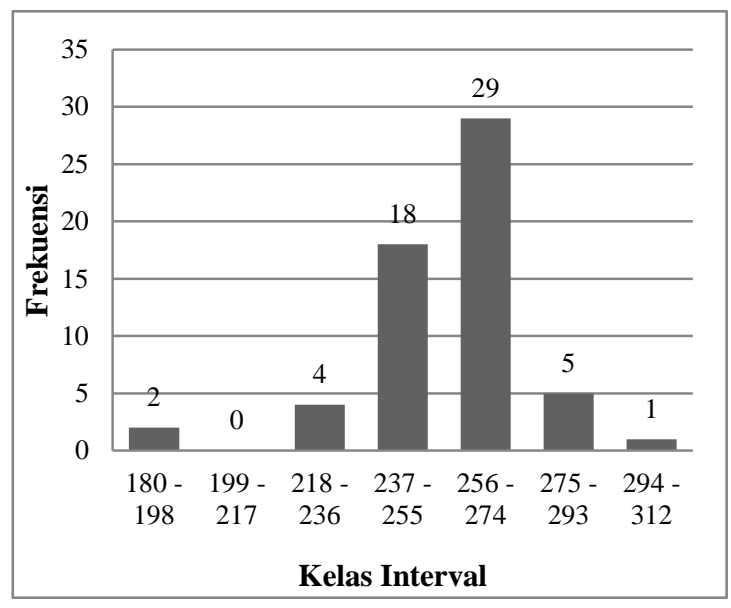

Gambar 7. Diagram Batang Distribusi Frekuensi Data Variabel Profil Calon Guru SMK-KKTP Menurut Persepsi Guru Pembimbing PPL

Rerata data hasil penelitian yang diperoleh adalah 257,14. Nilai tersebut lebih besar dibanding rerata kriteria sebesar 195, sehingga profil calon guru menurut persepsi guru 
pembimbing PPL termasuk kategori baik. Kecenderungan dari masing-masing skor disajikan dalam Tabel 19 dan Gambar 8.

Tabel 19. Persentase Kecenderungan Skor Variabel Profil Calon Guru SMKKKTP Menurut Persepsi Guru Pembimbing PPL

\begin{tabular}{clrr}
\hline Interval & \multicolumn{1}{c}{ Kategori } & \multicolumn{1}{c}{ Frek } & \multicolumn{1}{c}{$\%$} \\
\hline $273<X \leq 325$ & Sangat Baik & 8 & 14 \\
$221<X \leq 273$ & Baik & 49 & 83 \\
$169<X \leq 221$ & Kurang Baik & 2 & 3 \\
$117<X \leq 169$ & Tidak Baik & 0 & 0 \\
$65 \leq X \leq 117$ & Sangat Tidak Baik & 0 & 0 \\
\hline & Total & 59 & $100 \%$ \\
\hline
\end{tabular}

Kecenderungan Skor Variabel Profil Calon Guru SMK-KKTP Menurut Persepsi Guru Pembimbing PPL

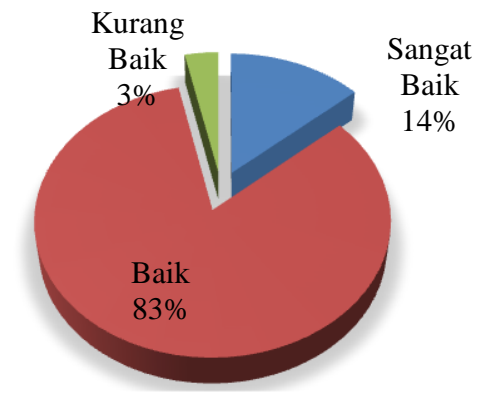

Gambar 8. Diagram Lingkaran Persentase Kecenderungan Skor Variabel Profil Calon Guru SMKKKTP Menurut Persepsi Guru Pembimbing PPL

Berdasarkan persentase kecenderungan data variabel tersebut dapat diketahui bahwa profil calon guru SMK-KKTP menurut persepsi guru pembimbing PPL secara umum cenderung termasuk dalam kategori kurang baik sampai sangat baik. Skor total yang diperoleh adalah 15.171 dan skor tertinggi yang ditetapkan adalah 19.175, maka pencapaian skornya adalah $79,12 \%$ dari skor tertinggi yang ditetapkan dengan kategori baik. Salah satu keunggulan yang menonjol dari mahasiswa calon guru menurut guru pembimbing PPL adalah kemampuan mahasiswa yang berkenaan dengan Teknologi Informasi dan Komunikasi (TIK). Namun demikian, terdapat kelamahan PPL menyangkut penyesuaian dengan kurikulum 2013, khususnya aspek perencanaan pembelajaran yang masih perlu ditingkatkan.

\section{Profil Calon Guru SMK-KKTP Menurut Persepsi Dosen}

Jumlah pernyataan dalam instrumen profil calon guru menurut persepsi dosen adalah 65 butir, sehingga rentang skor yang ditetapkan adalah mulai 65 sampai dengan 325, rerata kriteria (Mi) sebesar 195, dan simpangan baku kriteria (SDi) sebesar 43,33. Berdasarkan hasil analisis statistik deskriptif menggunakan software SPSS diketahui bahwa besarnya mean adalah 259; median 258; dan mode 181. Data tersebut memiliki standar deviasi 36,97 dan varian 1368,75 . Nilai minimum yang diperoleh adalah 181, nilai maksimumnya 300, dan jumlah skor total adalah 2331. Berdasarkan data tersebut dapat ditentukan besarnya range $(\mathrm{R})=300-181=119$; jumlah kelas $(\mathrm{K})=1+3,3 \log 9=4,15$ dibulatkan menjadi 4; dan panjang interval $(\mathrm{P})=$ $119: 4=29,75$ dibulatkan menjadi 30. Penyebaran skor datanya disajikan dalam Tabel 20.

Tabel 20. Tabel Distribusi Frekuensi Data Variabel Profil Calon Guru SMKKKTP Menurut Persepsi Dosen

\begin{tabular}{ccccc}
\hline No & Interval & Frek & $\begin{array}{c}\text { Frek. } \\
\text { Relatif }\end{array}$ & $\begin{array}{c}\text { Frek.Kumulatif } \\
\text { Relatif }\end{array}$ \\
\hline 1 & $181-210$ & 1 & $11,11 \%$ & $11,11 \%$ \\
2 & $211-240$ & 1 & $11,11 \%$ & $22,22 \%$ \\
3 & $241-270$ & 3 & $33,33 \%$ & $55,56 \%$ \\
4 & $271-300$ & 4 & $44,44 \%$ & $100 \%$ \\
\hline \multicolumn{2}{c}{ Jumlah } & 9 & $100 \%$ & \\
\hline
\end{tabular}

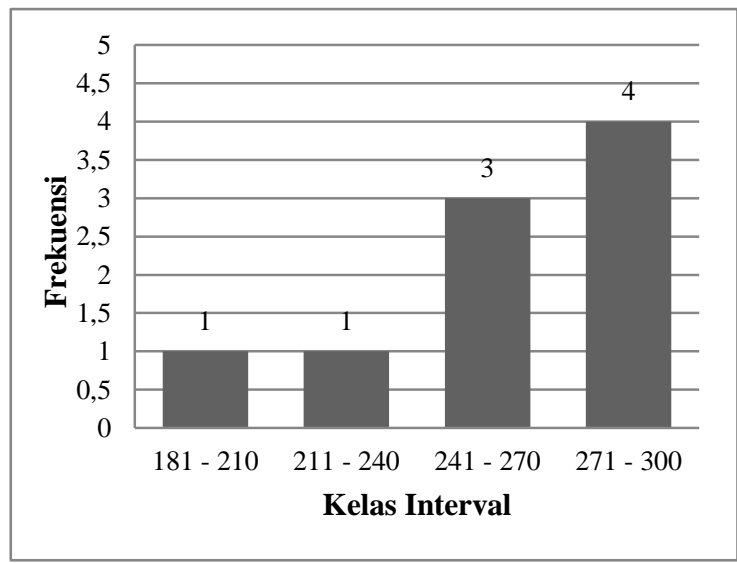

Gambar 9. Diagram Batang Distribusi Frekuensi Data Variabel Profil Calon Guru SMK-KKTP Menurut Persepsi Dosen 
Berdasarkan hasil perhitungan diperoleh rerata data hasil penelitian (empiris) sebesar 259. Nilai tersebut lebih besar dibanding rerata kriteria sebesar 195, sehingga profil calon guru SMK-KKTP menurut persepsi dosen secara keseluruhan termasuk kategori baik. Kecenderungan dari masing-masing skor dibedakan menjadi 5 kategori yang secara rinci disajikan dalam Tabel 21.

Tabel 21. Persentase Kecenderungan Skor Variabel Profil Calon Guru SMKKKTP Menurut Persepsi Dosen

\begin{tabular}{|c|c|c|c|}
\hline Interval & Kategori & Frek & $\%$ \\
\hline $273<X \leq 325$ & Sangat Baik & 4 & 44,44 \\
\hline $221<X \leq 273$ & Baik & 4 & 44,44 \\
\hline $169<X \leq 221$ & Kurang Baik & 1 & 11,11 \\
\hline $117<X \leq 169$ & Tidak Baik & 0 & 0 \\
\hline $65 \leq X \leq 117$ & Sangat Tidak Baik & 0 & 0 \\
\hline \multicolumn{2}{|c|}{ Total } & 9 & $100 \%$ \\
\hline
\end{tabular}

Persentase kecenderungan skornya dapat disajikan dalam bentuk diagram lingkaran pada Gambar 10.

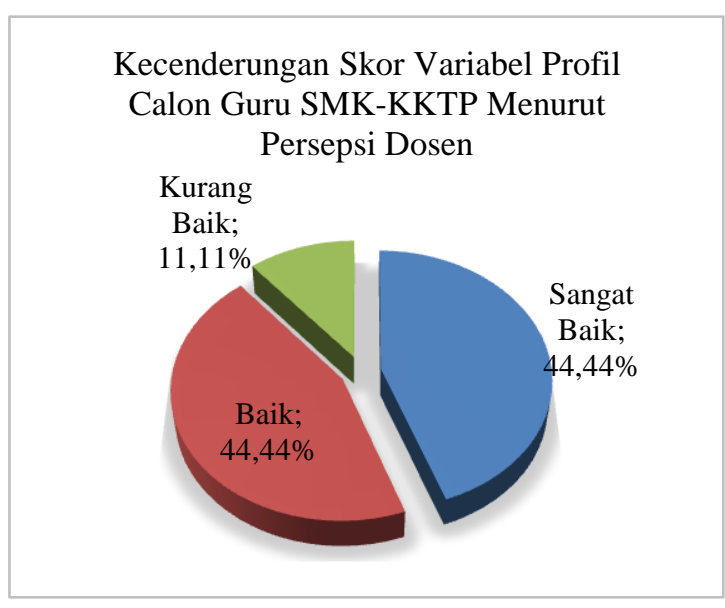

Gambar 10. Diagram Lingkaran Persentase Kecenderungan Skor Variabel Profil Calon Guru SMKKKTP Menurut Persepsi Dosen

Berdasarkan persentase kecenderungan data variabel tersebut dapat diketahui bahwa profil calon guru SMK-KKTP menurut persepsi dosen secara umum cenderung termasuk dalam kategori kurang baik sampai sangat baik. Skor total yang diperoleh adalah 2.331 dan skor tertinggi yang ditetapkan adalah
2.925, maka persentase pencapaian skornya adalah $79,69 \%$ dari skor tertinggi yang ditetapkan dengan kategori baik. Salah satu keunggulan pembelajaran di Prodi PTM FT UNY menurut dosen adalah bahwa mahasiswa diberi bekal kemampuan bidang TI yang memadai, serta kemampuan praktik yang baik.

\section{Profil Calon Guru SMK-KKTP Menurut Persepsi Mahasiswa}

Jumlah butir dalam instrumen profil calon guru menurut persepsi mahasiswa adalah 83 butir, sehingga rentang skor yang ditetapkan adalah mulai 83 sampai dengan 415, rerata kriteria (Mi) sebesar 249, dan simpangan baku kriteria (SDi) sebesar 55,33. Berdasarkan hasil analisis statistik deskriptif menggunakan software SPSS diketahui bahwa besarnya mean adalah 332,88; median 328; dan mode 312. Data tersebut memiliki standar deviasi 24,261 dan varian 588,589. Nilai minimum yang diperoleh adalah 281, nilai maksimumnya 403, dan jumlah skor total adalah 19.640. Berdasarkan data tersebut dapat ditentukan besarnya range $(\mathrm{R})=403-281=$ 122; jumlah kelas $(\mathrm{K})=1+3,3 \log 59=6,84$ dibulatkan menjadi 7; dan panjang interval (P) $=122: 7=17,43$ dibulatkan menjadi 18 . Penyebaran skor datanya disajikan dalam Tabel 22 .

Tabel 22. Distribusi Frekuensi Data Variabel Profil Calon Guru SMKKKTP Menurut Persepsi Mahasiswa

\begin{tabular}{|c|c|c|c|c|c|c|}
\hline \multirow{2}{*}{$\begin{array}{c}\text { No } \\
1\end{array}$} & \multicolumn{3}{|c|}{ Interval } & \multirow{2}{*}{$\begin{array}{r}\text { Frek } \\
2\end{array}$} & \multirow{2}{*}{$\begin{array}{c}\begin{array}{c}\text { Frek. } \\
\text { Relatif }\end{array} \\
3,39 \%\end{array}$} & \multirow{2}{*}{$\begin{array}{c}\begin{array}{c}\text { Frek. } \\
\text { Kumulatif } \\
\text { Relatif }\end{array} \\
3,39 \%\end{array}$} \\
\hline & 281 & - & 298 & & & \\
\hline 2 & 299 & - & 316 & 13 & $22,03 \%$ & $25,42 \%$ \\
\hline 3 & 317 & - & 334 & 19 & $32,20 \%$ & $57,63 \%$ \\
\hline 4 & 335 & - & 352 & 15 & $25,42 \%$ & $83,05 \%$ \\
\hline 5 & 353 & - & 370 & 5 & $8,47 \%$ & $91,53 \%$ \\
\hline 6 & 371 & - & 388 & 4 & $6,78 \%$ & $98,31 \%$ \\
\hline \multirow[t]{2}{*}{7} & 389 & - & 406 & 1 & $1,69 \%$ & $100 \%$ \\
\hline & \multicolumn{3}{|c|}{ Jumlah } & 59 & $100 \%$ & \\
\hline
\end{tabular}

Distribusi frekuensi data tersebut dapat disajikan dalam bentuk diagram batang pada Gambar 11. 


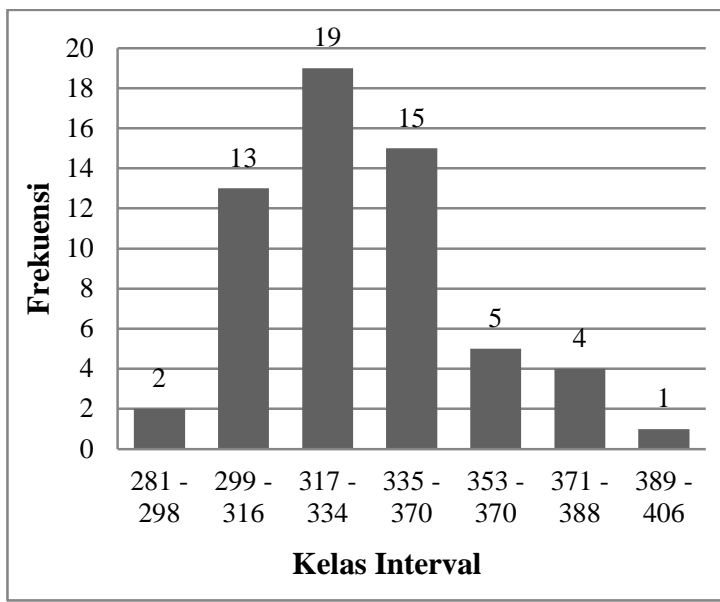

Gambar 11. Diagram Batang Distribusi Frekuensi Data Variabel Profil Calon Guru SMK-KKTP Menurut Persepsi Mahasiswa

Berdasarkan hasil perhitungan diperoleh rerata data hasil penelitian (empiris) sebesar 332,88. Nilai tersebut lebih besar dibanding rerata kriteria sebesar 249, sehingga profil calon guru SMK-KKTP menurut persepsi mahasiswa secara keseluruhan termasuk kategori baik. Kecenderungan dari masingmasing skor dibedakan menjadi 5 kategori yang secara rinci disajikan dalam Tabel 23 dan Gambar 12.

Tabel 23. Persentase Kecenderungan Skor Variabel Profil Calon Guru SMKKKTP Menurut Persepsi Mahasiswa

\begin{tabular}{clcc}
\hline Interval & \multicolumn{1}{c}{ Kategori } & Frek & $\%$ \\
\hline $348,6<X \leq 415$ & Sangat Baik & 17 & $29 \%$ \\
$282,2<X \leq 348,6$ & Baik & 41 & $69 \%$ \\
$215,8<X \leq 282,2$ & Kurang Baik & 1 & $2 \%$ \\
$149,4<X \leq 215,8$ & Tidak Baik & 0 & $0 \%$ \\
$83 \leq X \leq 149,4$ & Sangat Tidak Baik & 0 & $0 \%$ \\
\hline \multicolumn{2}{c}{ Total } & 59 & $100 \%$ \\
\hline
\end{tabular}

Berdasarkan persentase kecenderungan data variabel tersebut dapat diketahui bahwa profil calon guru SMK-KKTP menurut persepsi mahasiswa cenderung termasuk dalam kategori kurang baik sampai sangat baik. Skor total yang diperoleh adalah 19.640 dan skor tertinggi yang ditetapkan adalah 24.485, maka skor variabel profil calon guru SMK-KKTP menurut persepsi mahasiswa mencapai $80,21 \%$ dari skor tertinggi yang ditetapkan dengan kategori baik. Harapan mahasiswa untuk meningkatkan kompetensi adalah agar mata kuliah pengembangan kurikulum diberikan sebelum terjun melaksanakan PPL serta diberi bekal yang baik dalam kemampuan communication skill.

Kecenderungan Skor Variabel Profil

Calon Guru SMK-KKTP Menurut Persepsi Mahasiswa

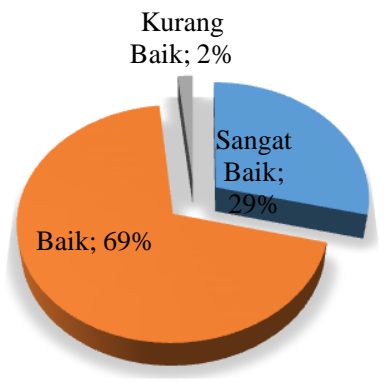

Gambar 12. Diagram Lingkaran

Persentase Kecenderungan Skor

Variabel Profil Calon Guru SMK-

KKTP Menurut Persepsi Mahasiswa

\section{SIMPULAN DAN SARAN}

\section{Simpulan}

Simpulan pada penelitian ini adalah sebagai berikut. Pertama, urgensi rumusan profil ideal guru SMK-KKTP termasuk kategori sangat penting. Kedua, profil ideal guru SMKKKTP terdiri atas 102 kompetensi yaitu: kompetensi pedagogik $=31$ butir; kompetensi bidang studi keahlian $=30$ butir; kompetensi manajerial $=7$ butir; kompetensi kepribadian $=22$ butir; dan kompetensi sosial $=12$ butir.

Ketiga, kurikulum Prodi PTM FT UNY option pemesinan sangat relevan dengan profil ideal guru SMK-KKTP. Keempat, terdapat 59 kompetensi yang tidak ada dalam rumusan profil ideal guru SMK-KKTP tetapi ada dalam kurikulum Prodi PTM FT UNY. Kelima, Pembelajaran di Prodi PTM FT UNY menurut persepsi dosen termasuk kategori sangat memadai dengan persentase pencapaian skor sebesar $84,26 \%$ dan menurut persepsi mahasiswa termasuk dalam kategori memadai dengan persentase pencapaian skor sebesar $77,89 \%$. Keenam, profil calon guru SMKKKTP menurut persepsi guru pembimbing PPL termasuk kategori baik dengan persentase pencapaian skor sebesar $79,12 \%$; menurut 
persepsi dosen termasuk kategori baik dengan persentase pencapaian skor sebesar 79,69\%; dan menurut persepsi mahasiswa termasuk kategori baik dengan persentase pencapaian skor sebesar $80,21 \%$.

\section{Saran}

Berdasarkan simpulan pada uraian sebelumnya, saran yang diajukan adalah sebagai berikut. Pertama, dalam proses penyusunan kurikulum pendidikan calon guru SMK khususnya kompetensi keahlian teknik pemesinan harus diawali kajian analisis kebutuhan dengan mengacu pada rumusan profil ideal guru SMK. Kedua, penyelenggara pendidikan calon guru SMK khususnya kompetensi keahlian teknik pemesinan harus selalu meningkatkan relevansi kurikulum dengan kebutuhan seorang guru teknik pemesinan di lapangan.

Ketiga, proses pembelajaran calon guru SMK-KKTP harus dioptimalkan baik dari sisi SDM pendidik maupun sarana dan prasarananya sehingga mampu memberikan bekal kompetensi yang memadai bagi mahasiswa calon guru. Pengurus jurusan, dosen, dan teknisi harus dapat menjadi teladan bagi calon guru dengan bertindak profesional sesuai kapasitasnya. Keempat, ntuk memantapkan kompetensi calon guru, pelaksanaan pembelajaran mikro perlu dioptimalkan dan setidaknya dilaksanakan dalam 3 SKS sehingga dapat memberi bekal yang memadai bagi mahasiswa saat melaksanakan PPL. Selain itu, dosen pengampu pembelajaran mikro perlu mengadakan workshop untuk menyamakan persepsi mengenai proses pembelajaran dan sistem penilaian. Keenam, Sekolah harus memberikan kesempatan dan akses seluas-luasnya bagi peserta PPL untuk dapat belajar bagaimana menjadi guru SMK yang profesional.

\section{DAFTAR PUSTAKA}

Azwar, S. (2014). Penyusunan skala psikologi. Yogyakarta: Pustaka Pelajar.

Department of Public Instruction. (2012). North carolina teacher evaluation process (Rev. ed.). North Carolina: Public School of North Carolina State Board of Education Department of Public Instruction.
Ditjen DIKTI. (2010a). Buku pedoman kerangka kualifikasi nasional indonesia. Jakarta: Direktorat Jenderal Pendidikan Tinggi Kementerian Pendidikan Nasional Republik Indonesia.

Ditjen DIKTI. (2010b). Kerangka kualifikasi nasional indonesia (Indonesian qualification framework) - Kajian tentang implikasi dan strategi implementasi KKNI. Jakarta: Direktorat Jenderal Pendidikan Tinggi Kementerian Pendidikan Nasional Republik Indonesia.

General Directorate of Education. (2010). Standars of professional competencies required of teachers. Spain: General Directorate of Education, Vocational Training and Learning Innovation.

Grollmann, P., \& Bauer, W. (2008). Technical and vocational education and training research for the professionalisation of vocational teachers. Dalam F. Rauner \& R. Maclean (Eds.), Handbook of Technical and Vocational Education and Training Research (pp. 385-392). Bremen: Springer.

Kompas. (2009). Banyak guru tak pantas jadi guru. Diambil pada tanggal 24 Oktober 2013, dari http://edukasi.kompas.com/read/2009/1 0/24/0604104/Banyak.Guru.Tak.Pantas Jadi.Guru.

Krejcie, R.V., \& Morgan, D.W. (1970). Determining sample size for research activities. Educational and Psychological Measurement, 30, pp.607-610.

Nurdjito. (2010). Evaluasi pencapaian kompetensi mahasiswa pendidikan teknik mesin FT UNY dalam praktik pengalaman lapangan di SMK se DIY. Tesis magister, tidak diterbitkan, Program Pascasarjana Universitas Negeri Yogyakarta, Yogyakarta.

Oklahoma Panhandle State University. (2012). Oklahoma panhandle state university teacher education handbook. Oklahoma: Oklahoma Panhandle State University.

Paryanto. (2009). Kemampuan mengajar lulusan fakultas teknik Universitas Negeri Yogyakarta. Tesis magister, tidak 
diterbitkan, Program Pascasarjana Universitas Negeri Yogyakarta, Yogyakarta.

Permendiknas. (2007a). Peraturan Menteri Pendidikan Nasional Republik Indonesia Nomor 16 Tahun 2007, tentang Standar Kualifikasi Akademik dan Kompetensi Guru.

Permendiknas. (2009b). Peraturan Menteri Pendidikan Nasional Nomor 39 Tahun 2009, tentang Pemenuhan Beban Kerja Guru dan Pengawas Satuan Pendidikan.

PP. (2008). Peraturan Pemerintah Nomor 74 Tahun 2008, tentang Guru.

Rauner, F., \& Dittrich, J. (2006). Increasing the profile and professionalisation of the education of TVET teachers and trainers. Dalam F. Bünning \& Z. Q. Zhao (Eds.), Education on the Treshold of Internationalisation (pp. 35-42). Bonn: InWEnt.

Republik Indonesia. (2005). Undang-Undang RI Nomor 14, Tahun 2005 tentang Guru dan Dosen.

Roelofs, E., \& Sanders, P. (2007). Towards a framework for assessing teacher competence. European Journal of Vocational Training, No 40 - 2007/1, 123139.

Rustad, S. et.al. (2013). Pedoman pengembangan kurikulum LPTK. Jakarta: Direktorat Jenderal Pendidikan Tinggi Kementerian Pendidikan dan Kebudayaan.

Schröder, T. (2013). Vocational teacher education and research as a task and challenge for the East and Southeast Asian region. Beijing: Deutsche Ge- sellschaft füf Internazionale Zusammenarbeit (GIZ) GmbH.

Scientific Report about Standards (tt). Current situation of competencies on teacher training and teacher training of vocational education teachers. Universitat Autònoma de Barcelona: Asia-Link Project.

Sekaran, U. (2003). Research methods for business, a skill building approach fourth edition. New York: John Wiley \& Sons, Inc.

Soeprijanto. (2010). Pengukuran kinerja guru praktek kejuruan. Jakarta: CV. Tursina.

Suyanto, \& Djihad, A. (2013). Bagaimana menjadi calon guru dan guru profesional. Yogyakarta: Multi Pressindo.

Wagiran. (2008, Juni). Butir-butir pemikiran pengembangan pendidikan vokasi secara holistik. Makalah disajikan dalam Seminar Internasional Revitalisasi Pendidikan Kejuruan dalam Pengembangan SDM Nasional, di Fakultas Teknik Universitas Negeri Padang.

Wagiran. (2013a). Kinerja guru-teori, penilaian dan upaya peningkatannya. Yogyakarta: Deepublish.

Wagiran. (2013b). Metodologi penelitian pendidikan (teori dan implementasi). Yogyakarta: Deepublish.

Widoyoko, S.E.P. (2013). Teknik penyusunan instrumen penelitian. Yogyakarta: Pustaka Pelajar.

Yunos, J.B.M., et.al. (2008). Technical \& vocational education \& training (TVET) from Malaysia perspective. Makalah disampaikan dalam 2nd International TT-TVET EU-Asia-Link project Meeting, VEDC Malang. 